\title{
In vitro development of the Mexican endemic twig epiphyte Erycina hyalinobulbon (Orchidaceae) to promote its conservation
}

\author{
Desarrollo in vitro de la orquídea epífita Erycina \\ hyalinobulbon (Orchidaceae), endémica de México, para \\ promover su conservación
}

Acta Botanica Mexicana

\author{
José Tonatiuh Gutiérrez-Zavala' (D), Irene Ávila-Díaz',2 (D), Rosa Elia Magaña-Lemus' (D)
}

\begin{abstract}
:
Background and Aims: Orchids in Mexico are mainly threatened by deforestation, changes in land use, illegal trade, deficiencies in environmental policy and legislation, and a lack of community participation in the conservation of their forests. Erycina hyalinobulbon is an endemic twig epiphyte orchid with a short life cycle and with large flowers in relation to its size, for which it has been harvested from its wild populations. The objectives of this work were to evaluate the in vitro development of $E$. hyalinobulbon in culture media with organic supplements, to compare sucrose vs. $\mathrm{N}^{\prime} J 0 y$ Stevia ${ }^{\circledR}$ as a carbon source for its initial stages of development, and to evaluate the development of its seedlings in media enriched with plant growth regulators (PGR).

Methods: For the sowing of seeds, Phytamax ${ }^{\mathrm{TM}}$ and MS medium at $30 \%$ of its basal salts were used in combination with organic supplement (coconut milk, pineapple puree and banana puree), along with the Phy medium used as control. In order to measure the effect of sucrose vs. $\mathrm{N}^{\prime} J o y$ Stevia ${ }^{\circledR}$ as a carbon source, these two treatments were used, with the Phytamax ${ }^{\mathrm{TM}}$ medium. To evaluate the development of seedlings with PGR, three treatments were tested: the $100 \%$ Phytamax $^{\mathrm{TM}}$ control, 30\% Phytamax $^{\mathrm{TM}}$ with $1.166 \mathrm{ml} / \mathrm{l}$ of Maxi-grow and the medium Chiu.

Key results: Phytamax ${ }^{\mathrm{TM}}$ medium added with banana promoted germination by $9.3 \%$, being a low cost and easy production option. Ninety days after sowing, $\mathrm{N}^{\prime}$ Joy Stevia ${ }^{\circledR}$ as a carbon source promoted germination by $8 \%$. The best development of the seedlings was registered in the medium Phytamax ${ }^{\mathrm{TM}}$ without PGR.
\end{abstract}

Conclusions: With this study, it was possible to develop an accessible in vitro propagation system for $E$. hyalinobulbon, in order to sustainably manage it and favor its conservation.

Key words: culture media, endemic orchid, in vitro culture, organic supplements, twig epiphyte orchid.

\section{Resumen:}

Antecedentes y Objetivos: Las orquídeas en México están amenazadas principalmente por deforestación, cambios de uso de suelo, comercio ilegal, carencias en la legislación y política ambiental y por una falta de participación de las comunidades para la conservación de sus bosques. Erycina hyalinobulbon es una orquídea endémica epífita de ramilla con un ciclo de vida corto y grandes flores en relación a su tamaño, por lo que ha sido extraída de sus poblaciones silvestres. Los objetivos de este trabajo fueron evaluar el desarrollo in vitro de $E$. hyalinobulbon en medios de cultivo con suplementos orgánicos, comparar la sacarosa vs. $\mathrm{N}^{\prime} J o y$ Stevia ${ }^{\circledR}$ como fuente de carbono en sus primeras etapas de desarrollo y evaluar el desarrollo de sus plántulas con medios enriquecidos con reguladores de crecimiento vegetal (PGR).

Métodos: Para la siembra de semillas los medios de cultivo Phytamax ${ }^{\mathrm{TM}}$ y MS, a $30 \%$ de sus sales basales, fueron utilizados con suplementos orgánicos (leche de coco, puré de piña y puré de plátano), utilizando el medio Phy como control. Para poder medir el efecto de la sacarosa vs. $\mathrm{N}^{\prime} J o y$ Stevia ${ }^{\circledR}$, se utilizaron estos dos tratamientos con el medio Phytamax ${ }^{\mathrm{TM}}$. Para evaluar el desarrollo de plántulas con PGR, se hicieron tres tratamientos: control de Phytamax ${ }^{\mathrm{TM}}$ 100\%, Phytamax ${ }^{\mathrm{TM}}$ 30\% con $1.166 \mathrm{ml} / \mathrm{I}$ de Maxi-grow y el medio Chiu.

Resultados clave: El medio Phytamax ${ }^{\mathrm{TM}}$ adicionado con plátano promovió la germinación en 9.3\%, siendo una opción de bajo costo y fácil producción. A los noventa días de efectuada la siembra, N’Joy Stevia ${ }^{\circledR}$ como fuente de carbono promovió la germinación con $8 \%$. El mejor desarrollo de las plántulas se obtuvo en el medio Phytamax ${ }^{\mathrm{TM}}$ sin PGR.

Conclusiones: Con este estudio se logró desarrollar un sistema de propagación in vitro de E. hyalinobulbon accesible para poder manejarla sustentablemente y favorecer su conservación.

Palabras clave: cultivo in vitro, medios de cultivo, orquídea endémica, orquídea epífita de ramilla, suplementos orgánicos.

${ }^{1}$ Universidad Michoacana de San Nicolás de Hidalgo, Received: November 1, 2020.

Facultad de Biología, Laboratorio de Biología de la Con- Reviewed: November 25, 2020.

servación Vegetal, Ciudad Universitaria, Edificio R plan-

ta baja, Avenida Francisco J. Múgica s/n, C.P. 58030

Morelia, Michoacán, México.

²Author for correspondence: irene.avila@umich.mx
Accepted by Marie-Stéphanie Samain: January 21, 2021.

Published Online first: February 12, 2021.

Published: Acta Botanica Mexicana 128 (2021).
To cite as: Gutiérrez-Zavala, J. T., I. Ávila-Díaz and R. E. Magaña-Lemus. 2021. In vitro development of the Mexican endemic twig epiphyte Erycina hyalinobulbon (Orchidaceae) to promote its conservation. Acta Botanica Mexicana 128: e1808. DOI: https://doi. org/10.21829/abm128.2021.1808

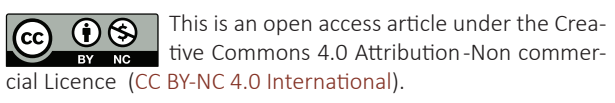

cial Licence (CC BY-NC 4.0 International).
e-ISSN: 2448-7589 


\section{Introduction}

Orchids have been used for their beauty in multiple ways; as ornamental plants they have acquired great importance and appreciation. For example, Taiwan exported in 2018, 73,930,000 Phalaenopsis Blume hybrids seedlings worldwide, generating 150,000,000 USD (AFA, 2019).

Mexico has 1239 identified species of orchids (Gámez-Montiel et al., 2016), which have an ornamental use, but have also been utilized to make glues, paste for religious figures, flavorings, and in traditional medicine (Hágsater et al., 2005). Orchids in Mexico are threatened, mainly due to deforestation and changes in land use (Menchaca and Moreno, 2011). In Mexico 16,575,924 hectares were deforested from 1976 to 2007, and in the state of Veracruz $47 \%$ of the epiphytic orchid species were registered as illegally traded (Flores-Palacios and Valencia-Díaz, 2007; Rosete-Vergés et al., 2014). In addition, there are deficiencies in the environmental policy and legislation with legal loopholes and no surveillance of illegal collectors and sellers, as well as a lack of community participation for the conservation of their forests (Menchaca and Moreno, 2011).

In vitro propagation is a technique that allows to produce a large number of plants due to the implementation of culture media with the necessary nutrients to achieve germination percentages of 80 to $100 \%$. These plants can be offered on the market to reduce the extraction pressure of individuals from wild populations (Ávila-Díaz et al., 2009; Menchaca et al., 2012). Diverse in vitro propagation protocols of epiphytic orchids have been developed, being successful the uses of Murashige \& Skoog culture media (Murashige and Skoog, 1962) (MS) (Ávila-Díaz et al., 2009; Paul et al., 2019), PhytamaxM (Ruíz et al., 2008; Pérez-Decelis et al., 2016), and Knudson C (Acemi and Özen, 2019; Pyati, 2019), among others, whether they are supplemented or not, and with plant growth promoters. The use of organic components can be a possible substitute for synthetic phytoregulators, lowering the costs to propagate orchids in vitro, as was the case of the MS medium supplemented with coconut water, which presented greater germination efficiency and the formation of seedlings in a Phalaenopsis hybrid (Salazar et al., 2013). Also, the usage of MS medium with pineapple was efficient in the development and growth of Cattleya trianae Linden \& Rchb. f. seedlings (Sala- zar and Vega, 2017), or in the case of Epidendrum chioneum Lindl., Epidendrum nocturnum Jacq., Oncidium ornithorhynchum Kunth (synonym of Oncidium pyramidale Lindl.) and Cyrtochilum revolutum (Lindl.) Dalström, the germination was benefited by $50 \%$ with MS culture medium enriched with banana pulp (Pérez-Martínez and Castañeda-Garzón, 2016).

Relatively few studies have been done on the in vitro propagation of twig epiphyte orchids (some include the species of the genus Erycina Lindl.), which can be distinguished from other epiphytes, because they are found on tree twigs and have short sexual maturity ages. Erycina crista-galli (Rchb. f.) N.H. Williams \& M.W. Chase reaches sexual maturity in one year, either in situ (Mondragón et al., 2007) or ex situ (Chiu and Chang, 2018). One of the twig epiphyte orchids with several published studies is Comparettia falcata Poepp. \& Endl., which was successfully propagated in modified Knudson $\mathrm{C}$ medium and symbiotic germination treatments with Rhizoctonia solani J.G. Kühn (Karol et al., 2014). Pedroza-Manrique et al. (2005) also evaluated the germination of $C$. falcata comparing the effects of 3-indoleacetic acid (IAA), 6-furfurylaminopurine (kinetin) and gibberellic acid $\left(\mathrm{GA}_{3}\right)$, being the combination of kinetin and $\mathrm{GA}_{3}$ the one that produced a positive response for germination and seedling development.

Erycina hyalinobulbon (La Llave \& Lex.) N.H. Williams \& M.W. Chase is an endemic twig epiphyte orchid of Mexico, distributed in the states of Nayarit, Jalisco, Michoacán, Mexico, Morelos, Guerrero and Oaxaca, with a relatively short life cycle and large flowers in relation to its size, with one to three inflorescence(s) per pseudobulb, four to 25 flowers, almost simultaneous, 5 to $10 \mathrm{~mm}$ in diameter, greenish-yellow dorsal sepal, greenish or yellow-greenish lateral sepals, and yellow lip (Jiménez et al., 1998) (Fig. 1A). The beauty of its flowers makes its extraction from its wild populations attractive in order to be sold as an ornamental plant. An investigation carried out by Sauno (2015) showed that $E$. hyalinobulbon grows optimally in media based on Phytamax $^{\text {TM }}$ 200\% (50 gr/l) and Triple 20, added with BA, obtaining high percentages of viability and germination. Due to the high cost of culture media prepared with commercial mineral salts (such as MS and Phytamax ${ }^{\mathrm{TM}}$ ) and phytoregulators (such as $\mathrm{BA}$ and $\mathrm{GA}_{3}$ ), the objective of this 

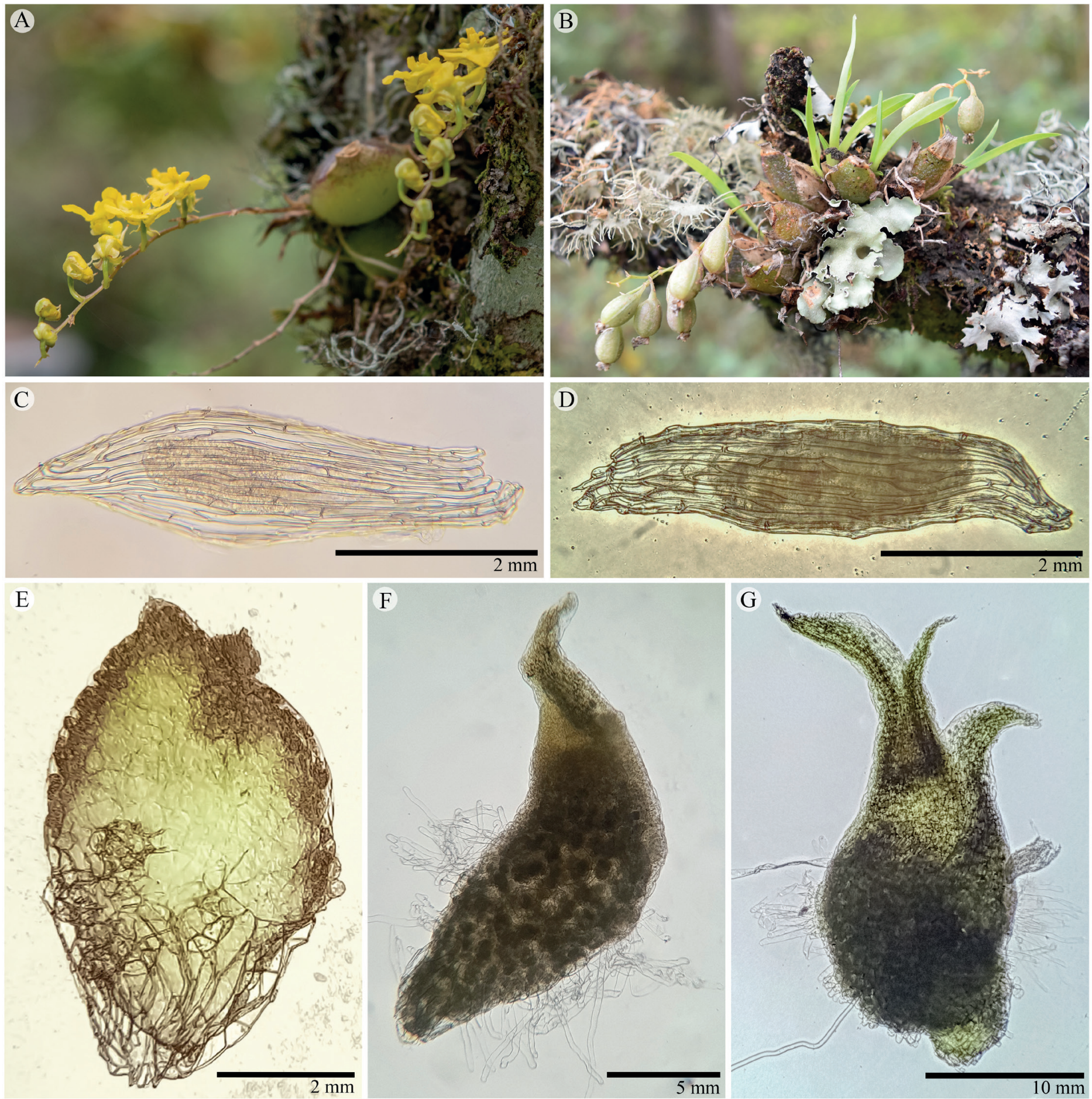

Figure 1: Erycina hyalinobulbon (La Llave \& Lex.) N.H. Williams \& M.W. Chase individuals. A. flowering plant in the Vasco de Quiroga Biological Station, Toreo el Alto community, Michoacán, Mexico; B. fruiting plant in the same locality. Seed viability categories: C. seed; D. protocorm 1; E. protocorm 2; F. seedling 1; G. seedling 2 (Photos: José Tonatiuh Gutiérrez Zavala).

work was to establish an efficient and low-cost in vitro germination protocol, with the hypothesis that culture media with organic supplements promote better germination and development of E. hyalinobulbon than conventional media.
The particular objectives of this work were: 1) Evaluate the in vitro development of $E$. hyalinobulbon in culture media with organic supplements; 2) Compare sucrose vs. N’Joy Stevia ${ }^{\circledR}$ (stevia) as a carbon source for its initial stages 
of development; 3) Evaluate the development of seedlings with culture media added with Plant Growth Regulators (PGR).

It is considered that the results can be used to favor the conservation of E. hyalinobulbon, through the massive production of this orchid by the communities that have it in their forests, and thus avoid the extraction of its environment.

\section{Materials and Methods}

\section{Establishment of in vitro culture}

On June 2018, 15 capsules (Fig. 1B) of E. hyalinobulbon were collected from a population at the Vasco de Quiroga Biological Station (EBVQ), that is under the auspices of the Faculty of Biology of the Universidad Michoacana de San Nicolás de Hidalgo. The EBVQ is located at the "La Alberca" ranch in the town of Toreo Alto, northwest of the urban area of Uruapan, Michoacán, Mexico, at 19²9'26.3"N latitude and $102^{\circ} 00^{\prime} 24.4^{\prime \prime} \mathrm{W}$ longitude.

The seeds were disinfected in $15 \%$ liquid detergent for $5 \mathrm{~min}, 70 \%$ ethanol for $5 \mathrm{~min}, 3 \%$ hydrogen peroxide for $5 \mathrm{~min}, 1.2 \%$ sodium hypochlorite for $5 \mathrm{~min}$ and rinsed with sterile distilled water (modified from Ávila-Díaz et al., 2009). The aseptic seeds were then transferred to culture media.

In vitro development of $E$. hyalinobulbon with organic supplements

For the sowing of seeds, the medium Phytamax ${ }^{\mathrm{TM}}$ Orchid Maintenance Medium without Charcoal (Phy) (SIGMA, St. Louis, Missouri, EUA) and MS medium (Murashige and Skoog, 1962) at $30 \%$ of its basal salts, added with $8 \mathrm{~g}$ bacteriological agar (BD Bioxon, Cuautitlán Izcalli, Mexico) and $20 \mathrm{~g}$ sucrose, were used in combination with organic supplements as shown in Table 1. The pineapple and banana were manually ground to puree, they were passed through a kitchen strainer to ensure that the paste was homogeneous; once the coconut was split, the endosperm was ground with the coconut water to create coconut milk. The organic supplements were added to each medium, the $\mathrm{pH}$ was adjusted to 5.7 with $\mathrm{pH}$-indicator strips McolorpHast ${ }^{\mathrm{TM}}$ (1.09535.0001, Darmstadt, Germany) and they were sterilized in an autoclave Kitlab (AE-22, USA) for 15 minutes at $121{ }^{\circ} \mathrm{C}, 1.2 \mathrm{~kg} \mathrm{~cm}-2$.
The observations were performed every month, with an optical microscope (MG-30PL, Cd. Mx., Mexico). The development of 150 individuals per treatment was registered based on the following categories: seed, protocorm 1 (globular embryo within the seed coat), protocorm 2 (embryo leaving $50 \%$ of the seed coat), seedling 1 (with one to two leaves) and seedling 2 (with three or more leaves) (Figs. 1C-G).

\section{Effect of sucrose vs. stevia as a carbon source}

Additionally, another Phy treatment was prepared at $30 \%$ of its basal salts added with $15 \mathrm{~g}$ bacteriological agar and $20 \mathrm{~g} \mathrm{~N}$ 'Joy Stevia $^{\circledR}$ (ingredients: dextrose $96.5 \%$, stevia 3.5\% and natural flavoring) (PhyS) to evaluate the germination effectiveness. Each treatment consisted of six flasks, with $20 \mathrm{ml}$ medium covered with aluminum caps. All the cultures were maintained under the same light conditions and ambient temperature, with a light intensity of $7.844 \mu \mathrm{mol}$ $\mathrm{m}^{-2} \mathrm{~s}^{-1}$ and in a temperature range of $26.5 \pm 3{ }^{\circ} \mathrm{C}$.

\section{In vitro seedling development of E. hyalinobul- bon}

To induce the development of seedlings, the following media were tested: medium Phy (100\%) added with $20 \mathrm{~g} / \mathrm{l}$ sucrose, $8 \mathrm{~g} / \mathrm{l}$ agar and a $\mathrm{pH}$ of 5.7, as a control (treatment Phyt). The second treatment was a Phy culture medium with $30 \%$ of its basal salts, plus $1.166 \mathrm{ml} / \mathrm{l}$ of a commercial product with Plant Growth Promoters (PGP) (Maxi-grow ${ }^{\circledR}$ ) with $20 \mathrm{~g} / \mathrm{l}$ sucrose, $8 \mathrm{~g} / \mathrm{l}$ agar and a pH of 5.7 (treatment Maxi). The third treatment was the culture medium described by Chiu and Chang (2018), but modified, which was named as subculture medium: $50 \% \mathrm{MS}$, supplemented with $0.5 \mathrm{mg} / \mathrm{l}$ niacin, $0.5 \mathrm{mg} / \mathrm{l}$ pyridoxine $\mathrm{HCl}, 0.1 \mathrm{mg} / \mathrm{l}$ thiamine $\mathrm{HCl}, 20$ $\mathrm{mg} / \mathrm{l}$ glycine, $100 \mathrm{mg} / \mathrm{l}$ myo-inositol, $170 \mathrm{mg} / \mathrm{l} \mathrm{NaH} \mathrm{PO}_{4^{\prime}} 1$ $\mathrm{g} / \mathrm{l}$ activated carbon, $1 \mathrm{~g} / \mathrm{l}$ peptone, $6 \mathrm{~g} / \mathrm{l}$ potato infusion, $150 \mathrm{ml} / \mathrm{l}$ coconut milk, $20 \mathrm{~g} / \mathrm{l}$ sucrose and $8 \mathrm{~g} / \mathrm{l}$ agar; the $\mathrm{pH}$ was adjusted to 5.2 (treatment Chiu). The shoots were subcultured each 60 days. Measurements were carried out at the beginning of the experiment, and every 30 days thereafter. In all cases, the increment $(\Delta)$ was calculated, with the difference of the final measurement minus the initial measurement. The parameters evaluated every 30 days were: number of leaves, size of two leaves (small and intermediate size), number of shoots, the size of two shoots 
Table 1: Culture media for sowing Erycina hyalinobulbon (La Llave \& Lex.) N.H. Williams \& M.W. Chase in combination with organic supplements

\begin{tabular}{|c|c|c|c|c|c|c|c|}
\hline Culture media & Phy (control) & Phyc & PhyP & PhyB & MSC & MSP & MSB \\
\hline $\begin{array}{l}\text { Organic } \\
\text { supplements }\end{array}$ & - & $\begin{array}{l}428.5 \mathrm{ml} / \mathrm{l} \\
\text { coconut milk }\end{array}$ & $\begin{array}{c}85.4 \mathrm{~g} / \mathrm{l} \\
\text { pineapple } \\
\text { puree }\end{array}$ & $\begin{array}{c}85.4 \mathrm{~g} / \mathrm{l} \text { banana } \\
\text { puree }\end{array}$ & $\begin{array}{l}428.5 \mathrm{ml} / \mathrm{l} \\
\text { coconut milk }\end{array}$ & $\begin{array}{c}85.4 \mathrm{~g} / \mathrm{l} \\
\text { pineapple } \\
\text { puree }\end{array}$ & $\begin{array}{c}85.4 \mathrm{~g} / \mathrm{l} \text { banana } \\
\text { puree }\end{array}$ \\
\hline
\end{tabular}

(small and intermediate size), the number of pseudobulbs, the length and width of a pseudobulb, the vigor (percentage of the green tissue-without any symptoms of disease or dehydration in relation to the total seedling), the number of roots and the size of a root.

\section{Statistical analysis}

The data about in vitro development of $E$. hyalinobulbon with organic supplements and with reference to the effect of sucrose $v s$. stevia as a carbon source were analyzed using the program SAS version 8 (SAS Institute, 2008), applying a Pearson ChiSquare test. Subsequently, a correspondence analysis was performed.

The data about in vitro seedling development of $E$. hyalinobulbon were analyzed using the program $\mathrm{R}$ version 3.5.1 (R Core Team, 2018), applying the ANOVA and TukeyHSD tests with $95 \%$ significance.

\section{Results}

\section{In vitro development of E. hyalinobulbon with or-} ganic supplements

After 60 days, significant differences were observed in the development of $E$. hyalinobulbon between the different treatments (ChiSquare $=43.725, \mathrm{DF}=18, \mathrm{p}=0.0006$ ), noting that the PhyB treatment was the best to promote the development of $E$. hyalinobulbon, with respect to the control.

At 90 days after sowing, medium PhyB was the best for the development of E. hyalinobulbon (Fig. 2). Significant differences were recorded in the development between the tested treatments (ChiSquare=63.696, DF=18, $p=0.0001)$. The correspondence analysis showed that the only significantly different medium was PhyB with respect to the control.

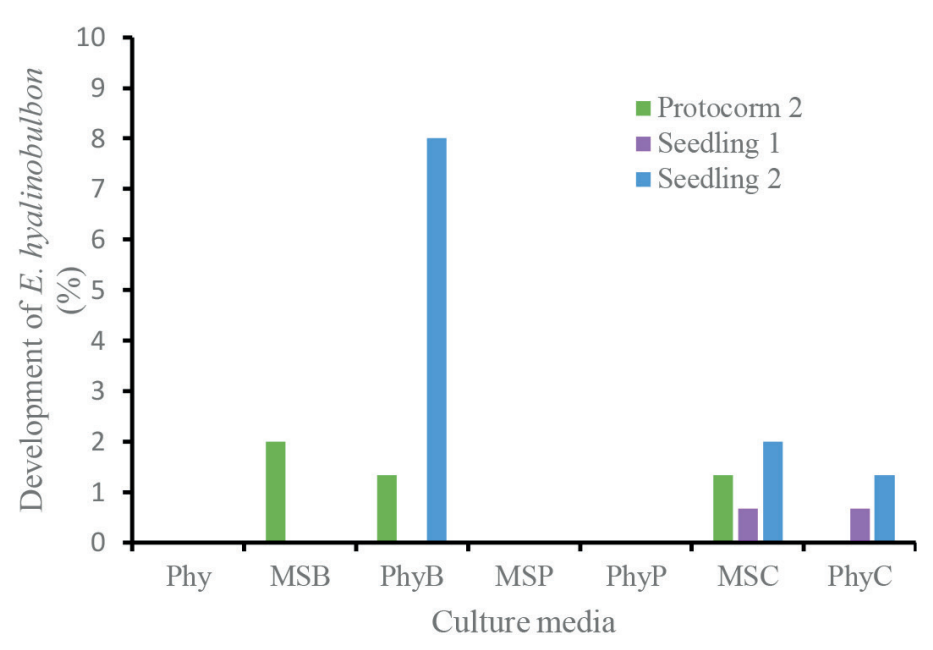

Figure 2: Germination and development of Erycina hyalinobulbon (La Llave \& Lex.) N.H. Williams \& M.W. Chase in culture media with organic supplements 90 days after sowing; from left to right: Phy $(30 \%$ Phytamax $\left.{ }^{\mathrm{TM}}\right), \mathrm{MSB}(30 \% \mathrm{MS}$ supplemented with banana), PhyB (30\% Phytamax $^{\mathrm{TM}}$ supplemented with banana), MSP (30\% MS supplemented with pineapple), PhyP (30\% Phytamax ${ }^{\mathrm{TM}}$ supplemented with pineapple), MSC (30\% MS supplemented with coconut) and PhyC (30\% Phytamax ${ }^{\mathrm{TM}}$ supplemented with coconut).

\section{Effect of sucrose vs. stevia as a carbon source}

The development of $E$. hyalinobulbon 90 days after the sowing in the different carbon sources, with sucrose and stevia, showed significant differences, with the ChiSquare test (ChiSquare $=12.500, D F=3, p=0.0059$ ) being higher with stevia (Table 2). At 120 days there were no significant differences between using sucrose or stevia as a carbon source.

\section{In vitro seedling development of E. hyalinobulbon} Regarding the size of the roots, there were significant differences in shoots rooting after 150 days, between Phyt vs. Chiu and Phyt vs. Maxi, being the Phyt medium the one 
Table 2: In vitro development of Erycina hyalinobulbon (La Llave \& Lex.) N.H. Williams \& M.W. Chase 90 days after the sowing in different carbon sources: sucrose vs. stevia.

Treatment Protocorm 1 Protocorm 2 Seedling $1 \quad$ Seedling 2

\begin{tabular}{lllll}
\hline Sucrose & 150 & 0 & 0 & 0 \\
Stevia & 138 & 2 & 1 & 9 \\
\hline
\end{tabular}

that promotes better root development. Between Chiu and Maxi media there were no significant differences (Fig. 3A). The number of leaves, number of shoots and size of shoots, 150 days after sowing, compared with the Tukey test, show that there were no significant differences between the Phyt and Chiu media, while the comparison of the Maxi medium against the previous two shows that there were significant differences, the Phyt and Chiu media being better (Figs. 3BD). For the size of leaves and the number of roots, the Tukey test at 150 days after sowing showed significant differences between the Phyt and Maxi media, but not between Chiu vs. Phyt and Chiu vs. Maxi (Figs. 3E-F). Regarding the number of pseudobulbs and the length $\times$ width of the pseudob$u l b$, there were no significant differences. The graphs show negative numbers due to the fact that in some treatments the plants withered, and various healthy tissues and organs were severely affected. These values were exhibited when subtracting from the initial measurement to the final one.

\section{Discussion}

In vitro development of E. hyalinobulbon with organic supplements

In this study, the better percentage of germination (9.3\%) was obtained in the Phytamax ${ }^{\mathrm{TM}}$ medium with $30 \%$ of its basal salts, added with banana puree as an organic supplement, which represents a much lower cost in the acquisition of inputs and allows greater accessibility to reproduce this species. The addition of organic supplements to the culture media improves the development and lower production costs of orchids (Moreno and Menchaca, 2007; Pakum et al., 2016; Salazar and Vega, 2017). In general, it has been reported that adding banana to the growing media improves the development of the plant and the roots
(Azlan et al., 2016; Menezes et al., 2016; Wida and Hariyanto, 2019). It has been reported that banana pulp contains natural cytokinins, mineral, carbohydrate, amino acids, niacin, vitamins, fatty acids, cellulose, sterols and polyols, which are useful for the development of plantlets (Tamura, 1970; Arditti, 2008). With respect to the results obtained by Sauno (2015), a 100\% germination and viability is reported with the use of Phytamax ${ }^{\mathrm{TM}}$ containing $200 \%$ straight salts, added with $0.05 \mathrm{mg} / \mathrm{l}$ benzyladenine (BA). Sauno (2015) reports at 45 days a $0 \%$ viability with the application of $200 \%$ Phytamax ${ }^{\mathrm{TM}}$ medium without the addition of BA. Comparing this with our results, the decrease of up to $30 \%$ of the basal salts of Phytamax ${ }^{\mathrm{TM}}$ allows the individuals to remain viable and develop, since in the present study $10 \%$ of seedlings with two or more leaves and one or more roots were recorded at 120 days. Aguilar-Morales et al. (2016) compared the germination of Encyclia adenocaula (La Llave \& Lex.) Schltr. in three treatments based on MS, with $1 \mathrm{~g} / \mathrm{I}$ charcoal, $10 \%$ banana extract and $10 \%$ coconut water, where the best medium was the one with charcoal, obtaining $56.9 \%$ germination at 30 days, and the slowest was the banana extract with $23 \%$ germination at 59 days. In contrast, in this research, the best treatment was Phytamax ${ }^{\mathrm{TM}}$ to which $8.5 \%$ banana was added, and $9.3 \%$ germination was recorded at 90 days.

Starting an orchid production project is usually expensive due to the equipment that includes laboratory balance, laminar flow hood among others and supplies like PGR, such as auxins and citokinins, which are needed to propagate these plants. One way to lower production costs is to use organic supplements. Although the percentage of germination with the medium proposed here is low (9.3\%), there are many seeds in the orchid capsules. As reported by Damon and Valle-Mora (2008), on average 17,709 seeds per capsule for E. crista-galli are found. In this case, the conservation program can be established with the seedlings obtained, these being sufficient.

\section{Effect of sucrose vs. stevia as a carbon source} Few studies have been carried out on the effect of stevia on the in vitro development of plants; one of these is the one carried out by Taha et al. (2016), where they compared the implementation of a solution of Stevia rebaudiana Bertoni 

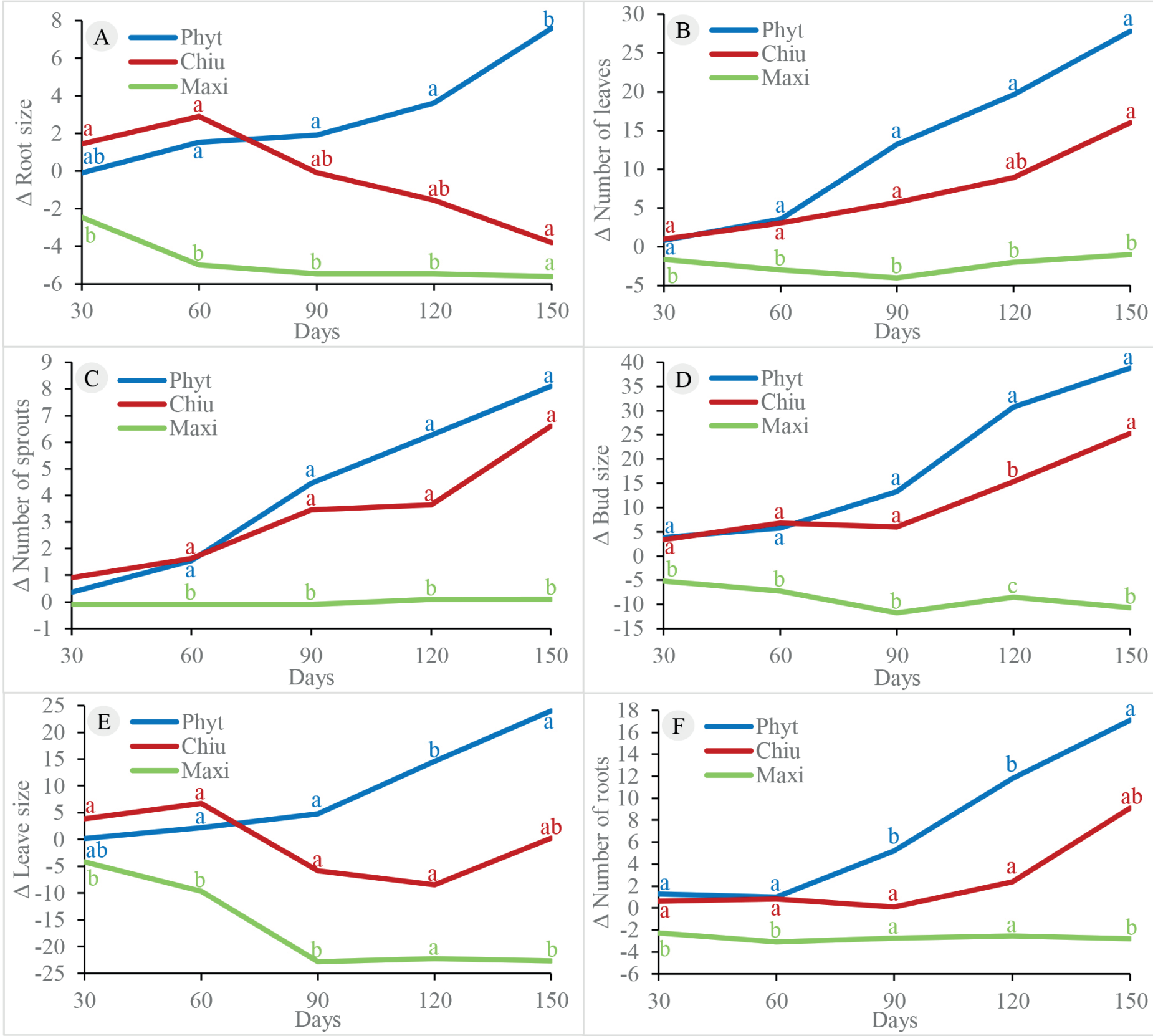

Figure 3: Development of Erycina hyalinobulbon (La Llave \& Lex.) N.H. Williams \& M.W. Chase in culture media: Phytamax ${ }^{\mathrm{TM}}$ at $100 \%$ of its basal salts (Phyt), the subculture medium described by Chiu and Chang (2018) (Chiu), Phytamax ${ }^{\mathrm{TM}}$ at $70 \%$ of its basal salts, plus $30 \%$ of the recommended concentration of Maxigrow (Maxi). A. $\Delta$ root size; B. $\Delta$ number of leaves; C. $\Delta$ number of sprouts; D. $\Delta$ bud size; E. $\Delta$ leave size; F. $\Delta$ number of roots. The different letter indicates significant differences with respect to the other treatments $(p<0.05)$. The increment $(\Delta)$ was calculated, with the difference of the final measurement minus the initial measurement.

leaves vs. sucrose and combinations of both. They obtained that with the use of stevia the multiplication and growth of Simmondsia chinensis C.K. Schneid. improved, but the combination of $20 \mathrm{~g} / \mathrm{l}$ sucrose plus $7 \mathrm{ml}$ stevia turned out to be better for the number of shoots and leaves and for the length of the shoot. Altamirano et al. (2017) carried out an investigation with the sweetener CANDEREL ${ }^{\circledR}$ stevia, using it as the carbon source for Cuitlauzina pendula Lex., concluding that the inclusion of $10,15,20,25 \mathrm{~g} /$ I CANDEREL ${ }^{\circledR}$ stevia or $25 \mathrm{~g} / \mathrm{l}$ sucrose does not present significant diffe- 
rences for the height measurements of the seedlings. In the present work N’Joy Stevia ${ }^{\circledR}$ was applied as a carbon source during the in vitro development process of $E$. hyalinobulbon in a concentration of $20 \mathrm{~g} / \mathrm{l}$ vs. $20 \mathrm{~g} / \mathrm{l}$ of sucrose, obtaining better development with N'Joy Stevia ${ }^{\circledR}$ at 90 days after sowing. At 120 days after sowing, we observed results similar to those of Altamirano et al. (2017), since there are no significant differences in the germination percentages. However, we recommend the use of $\mathrm{N}^{\prime}$ Joy Stevia ${ }^{\circledR}$ as carbon source if the acceleration of the germination process is desired.

\section{In vitro seedling development of E. hyalinobulbon} Chiu and Chang (2018) obtained a good development and the subsequent flowering of Erycina pusilla (L.) N.H. Williams \& M.W. Chase. In this research where we compared the Chiu, Maxi and Phyt media, the latter was the medium that favored the development of $E$. hyalinobulbon roots. In the other variables, there were no significant differences in its growth between the implementation of the Chiu and Phyt medium, so that Phyt medium is recommended for the development of $E$. hyalinobulbon, for promoting root development, ease of preparation and low cost of inputs compared to Chiu. The Maxi medium was the one that presented the lowest development, so we do not recommend its use.

\section{Conclusions}

With this study, it was possible to develop an accessible in vitro propagation system for $E$. hyalinobulbon with the PhyB medium, which is a low-cost and easy to produce option for the in vitro development of this orchid. In addition, it is shown that sucrose can also be substituted by N'Joy Ste$\mathrm{via}^{\circledR}$ as a carbon source to accelerate its development. For a greater development of individuals the use of the Phyt medium is recommended for being an easy medium to prepare and its lower initial cost compared to Chiu. As a continuation of this work, it is suggested to investigate the combined use of stevia with sucrose for the germination and more efficient in vitro development of $E$. hyalinobulbon, also on different concentrations of the Phytamax ${ }^{\mathrm{TM}}$ medium combined with banana.

These results can contribute to an accessible management of $E$. hyalinobulbon in local human communities, and thus benefit its conservation.

\section{Author contributions}

IAD conceived this study, IAD and JGZ designed the study, JGZ and RML carried out the preparation of culture media and data collection, JGZ performed the statistical analysis of the data, JGZ and IAD interpreted the data, JGZ and IAD drafted the manuscript. All authors contributed to the review and approval of the final manuscript.

\section{Funding}

This study was sponsored by the Coordinación de la Investigación Científica $(\mathrm{CIC})$ de la Universidad Michoacana de San Nicolás de Hidalgo, through the project: "Conservation Biology of Michoacan Orchids", whose responsible is IAD.

\section{Acknowledgements}

To the Bautista family for providing the facilities to carry out this work at the Vasco de Quiroga Biological Station, to Rosa Isabel Fuentes Chávez and Rosalba Sánchez Velázquez for their help in the field. To Yvonne Herrerías Diego for her help with some of the statistical analyses.

\section{Literature cited}

Acemi, A. and F. Özen. 2019. Optimization of in vitro asymbiotic seed germination protocol for Serapias vomeracea. The EuroBiotech Journal 3(3): 91-95. DOI: https://doi.org/10.2478/ ebtj-2019-0017

AFA. 2019. Taiwan and EU mutually recognize DUS report of Phalaenopsis for expanding orchid business. https://www.afa. gov.tw/ (consulted January, 2020).

Aguilar-Morales, M. A., A. Laguna-Cerda, C. Vences-Contreras and H. E. Lee-Espinosa. 2016. Análisis de semillas de Encyclia adenocaula (La Llave \& Lex.) Schltr (Orchidaceae) para su conservación ex situ. Revista Mexicana de Ciencias Agrícolas 7(7): 1741-1747. DOI: https://doi.org/10.29312/remexca.v7i7.166

Altamirano, J. C., A. I. Cabezas and D. García. 2017. Efecto de edulcorante a base de Stevia rebaudiana en el cultivo in vitro de Cuitlauzina pendula. Biotecnología Vegetal 17(2): 135-141.

Arditti, J. 2008. Micropropagation of orchids, Vol. I. Blackwell Publishing. Oxford, UK. 1523 pp.

Ávila-Díaz, I., K. Oyama, C. Gómez-Alonso and R. Salgado-Garciglia. 2009. In vitro propagation of the endangered orchid Laelia speciosa. Plant Cell Tissue and Organ Culture 99: 335-343. DOI: https://doi.org/10.1007/s11240-009-9609-8 
Azlan, J., H. Indan, S. N. Abdullah, D. David, H. Marbawi and R. Jawan. 2016. Effects of organic additives and plant growth regulators on protocorm development of Dendrobium lowii. Transactions on Science and Technology 3(3): 462-468.

Chiu, Y. T. and C. Chang. 2018. In vitro flowering and breeding of Erycina pusilla. In: Lee, Y. L. and E. T. Yeung (eds.). Orchid propagation: from laboratories to greenhouses-methods and protocols. Springer Protocols Handbooks/Humana Press. New York, USA. Pp. 257-265. DOI: https://doi. org/10.1007/978-1-4939-7771-0_13

Damon, A. and J. Valle-Mora. 2008. Retrospective spatial analysis of the pollination of two miniature epiphytic orchids with different pollination strategies in a coffee plantation in Soconusco, Chiapas, Mexico. Botanical Journal of the Linnean Society 158(3): 448-459. DOI: https://doi.org/10.1111/ j.1095-8339.2008.00857.x

Flores-Palacios, A. and S. Valencia-Díaz. 2007. Local illegal trade reveals unknown diversity and involves a high species richness of wild vascular epiphytes. Biological Conservation 136(3): 372-387. DOI: https://doi.org/10.1016/j.biocon.2006.12.017

Gámez-Montiel, O., E. Villavicencio-Gutiérrez, M. A. SerratoCruz, J. M. Mejía-Muñoz, M. G. Treviño-de Castro, H. L. Martínez-González, M. Rodríguez-Olvera, L. Granada-Carreto, M. Flores-Cruz, J. Reyes-Santiago, M. Á. Islas-Luna, E. Salomé-Castañeda, R. A. Menchaca-García, C. M. EspadasManrique, L. Hernández-Sandoval, L. M. Vázquez-García, M. T. B. Colinas-León, F. Martínez-Martínez, O. VargasPonce and E. Ríos-Santos. 2016. Conservación y aprovechamiento sostenible de especies ornamentales nativas de México. Servicio Nacional de Inspección y Certificación de Semillas y Universidad Autónoma Chapingo. Cd. Mx., México. Pp. 14-17.

Hágsater, E., M. Á. Soto, G. A. Salazar, R. Jiménez, M. A. López and R. L. Dressler. 2005. Las orquídeas de México. Instituto Chinoín. Cd. Mx., México. 304 pp.

Jiménez, R., L. Sánchez and J. García-Cruz. 1998. Orchidaceae. Flora del Bajío y de Regiones Adyacentes 67: 52-55.

Karol, H., A. T. Mosquera-Espinosa and J. T. Otero. 2014. Propagación in vitro de semillas de la orquídea Comparettia falcata Poepp. \& Endl. (Orchidaceae) mediante técnicas simbióticas y asimbióticas. Acta Agronómica 64(2): 125-133. DOI: https://doi.org/10.15446/acag.v64n2.42976
Menchaca, R. A. and D. Moreno. 2011. Conservación de orquídeas, una tarea de todos. Universidad Autónoma Chapingo. Texcoco, México. 43 pp.

Menchaca, R. A., M. Á. Lozano and L. Sánchez. 2012. Estrategias para el aprovechamiento sustentable de las orquídeas de México. Revista Mexicana de Ciencias Forestales 3(13): 9-16.

Menezes, L. M., M. de F. P. S. Machado, P. Ballesta, F. Mora, M. A. Milaneze and C. Aparecida. 2016. Suplementos orgánicos para el cultivo in vitro del híbrido Laeliocattleya (Orchidaceae). IDESIA 34(1): 47-54. DOI: https://doi.org/10.4067/ S0718-34292016000100006

Mondragón, D., C. Maldonado and R. Aguilar-Santelises. 2007. Life history and demography of a twig epiphyte: a case study of Erycina crista-galli (Orchidaceae). Selbyana 28(2): 137-144.

Moreno, D. and R. A. Menchaca. 2007. Efecto de los compuestos orgánicos en la propagación in vitro de Stanhopea tigrina Bateman (Orchidaceae). Foresta Veracruzana 9(2): 27-32.

Murashige, T. and F. Skoog. 1962. A revised medium for rapid growth and bioassays with tobacco tissue cultures. Physiologia Plantarum 15: 473-497.

Pakum, W., S. Watthana, K. Srimuang and A. Kongbangkerd. 2016. Influence of medium component on in vitro propagation of Thai's endangered orchid: Bulbophyllum nipondhii Seidenf. Plant Tissue Culture and Biotechnology 25(1): 37-46. DOI: https://doi.org/10.3329/ptcb.v26i1.29765

Paul, M., T. Islam, R. Hari and M. Imdadul. 2019. In vitro Mass Propagation of Cymbidium aloifolium (L.) Sw. Plant Tissue Culture and Biotechnology 29(1): 73-79. DOI: https://doi. org/10.3329/ptcb.v29i1.41980

Pedroza-Manrique, J., C. Fernández-Lizarazo and A. Suarez-Silva. 2005. Evaluation of the effect of three growth regulators in the germination of Comparettia falcata seeds under in vitro conditions. In vitro Cellular and Developmental Biology-Plant 41(6): 838-843. DOI: https://doi.org/10.1079/IVP2005698

Pérez-Decelis, V. A., I. Ávila-Díaz and R. Salgado-Garciglia. 2016. Propagación in vitro de Cuitlauzina pendula La Llave \& Lex. (Orchidaceae) como una alternativa para su conservación. Biotecnología y Sustentabilidad 1(1): 91-95.

Pérez-Martínez, B. A. and S. L. Castañeda-Garzón. 2016. Propagación in vitro de orquídeas nativas como una contribución para la conservación ex situ. Biotecnología Vegetal 16(3): 143-151.

Pyati, A. N. 2019. Germinación de semillas in vitro, formación de protocolos y regeneración de plántulas en Aerides ringens 
Fisher. Plant Tissue Culture and Biotechnology 29(1): 49-62. DOI: https://doi.org/10.3329/ptcb.v29i1.41978

R Core Team. 2018. R: A language and environment for statistical computing. R Foundation for Statistical Computing. Vienna, Austria. http://www.R-project.org/

Rosete-Vergés, F. A., J. L. Pérez-Damián, M. Villalobos-Delgado, E. N. Navarro-Salas, E. Salinas-Chávez and R. RemondNoa. 2014. El avance de la deforestación en México 19762007. Madera y Bosques 20(1): 21-35. DOI: https://doi. org/10.21829/myb.2014.201173

Ruíz, B. C., C. A. Laguna, A. L. G. Iglesias, A. Damon, H. T. N. J. Marín, R. H. S. Azpíroz and M. J. L. Moreno. 2008. In vitro germination of Encyclia adenocaula (La Llave \& Lex.) Schltr. (Orchidaceae) seeds. Phyton 77(1): 203-215. DOI: https:// doi.org/10.32604/phyton.2008.77.203

Salazar, S. A. and N. A. Vega. 2017. Asymbiotic seed germination and in vitro propagation of Cattleya trianae Linden \& Reichb. f. (Orchidaceae). Acta Agronómica 66(4): 544-548. DOI: https://doi.org/10.15446/acag.v66n4.63597

Salazar, S. A., A. Z. Amaya and F. Barrientos. 2013. Evaluación de diferentes medios de cultivo in vitro en el desarrollo de híbridos de Phalaenopsis (Orchidaceae). Revista Colombiana de Biotecnología 15(2): 97-105. DOI: https://doi. org/10.15446/rev.colomb.biote.v15n2.41268

SAS Institute. 2008. SAS Procedures Guide: Version 8 (Vol. 1) SAS Institute. Cary, USA.

Sauno, R. 2015. Establecimiento de las condiciones de germinación y propagación in vitro de Erycina hyalinobulbon (Orchidaceae). Tesis de licenciatura. Facultad de Biología, Universidad Michoacana de San Nicolás de Hidalgo. Morelia, Michoacán, México. 62 pp.

Taha, R. A., S. A. M. Hassan, D. M. M. A. and N. S. Zaied. 2016. A comparative study on different cytokinin types and carbon source concentrations on in vitro proliferation of jojoba (Simmondsia chinesis link (Schneider)). International Journal of ChemTech Research 9(8): 178-184.

Tamura, S. 1970. Amino Acid Composition of Food in Japan. Japan Agricultural Research Quarterly 5(2): 56-60.

Wida, E. S. and S. Hariyanto. 2019. In vitro seed germination and seedling development of a rare indonesian native orchid Phalaenopsis amboinensis J.J. Sm. Scientifica 2019(8105138): 1-6. DOI: https://doi.org/10.1155/2019/8105138 